Research Article

\title{
Female Sexual Function after Vaginal Delivery with Episiotomy and Cesarean Section
}

\author{
Fungsi Seksual Perempuan Pascapersalinan Pervaginam \\ dengan Episiotomi dan Seksio Sesarea
}

\author{
I Made W Jembawan, I Made Darmayasa \\ Department of Obstetrics and Gynecology \\ Faculty of Medicine University of Udayana/ \\ RSUP Sanglah Hospital \\ Denpasar
}

\begin{abstract}
Objective: To determine the difference of sexual function after vaginal delivery with episiotomy and cesarean section in Sanglah Hospital, Denpasar.

Method: This research was conducted using cross sectional method. Sample was collected using consecutive sampling, starting from October 2011-September 2012. Our sample consists of 86 women, 43 post-episiotomy and 43 post-cesarean section. Sexual function was assessed using FSFI (Female Sexual Function Index). Total score was analyzed using independent t-test and difference of sexual function was tested using Chi-square, with significance level $\mathrm{p}<0.05$.

Result: Subject characteristics in both groups did not differ significantly. The average time to first sexual intercourse in both groups was 3 months after delivery ( $p>0.05$ ). There was no significant difference between the two groups in term of sexual arousal and lubrication, with p-value 0.160 and 0.67 , respectively. However, we found significant difference in other domains, namely desire $(\mathrm{p}=0.014)$, orgasm $(\mathrm{p}=0.045)$, satisfaction $(\mathrm{p}=0.018)$, pain $(\mathrm{p}=0.02)$, and total FSFI score $(\mathrm{p}=0.006)$. Sexual dysfunction was found in $18.60 \%$ of the episiotomy group and $2.33 \%$ of the cesarean section group, with $\mathrm{p}=0.030$.
\end{abstract}

Conclusion: Female sexual dysfunction was found to be significantly different between women post vaginal delivery with episiotomy and women who had cesarean section.

[Indones J Obstet Gynecol 2014; 4: 199-203]

Keywords: cesarean section, episiotomy, female sexual function

\begin{abstract}
Abstrak
Tujuan: Untuk mengetahui perbedaan fungsi seksual pascapersalinan pervaginam dengan episiotomi dan pascaseksio sesarea di Rumah Sakit Sanglah, Denpasar.
\end{abstract}

Metode: Penelitian ini menggunakan rancangan potong lintang. Rekrutmen sampel dilakukan secara consecutive sampling dari bulan Oktober 2011 sampai dengan September 2012. Didapatkan 86 sampel yang memenuhi kriteria inklusi dan kriteria eksklusi, yang terdiri dari 43 pasien pascaepisiotomi dan 43 pasien pascaseksio sesarea. Selanjutnya fungsi seksual dinilai dengan pengisian kuesioner FSFI (Female Sexual Function Index). Skor total kuesioner dianalisis dengan uji t independen, dan perbedaan fungsi seksual diuji menggunakan uji ChiSquare, dengan tingkat kemaknaan $p<0,05$.

Hasil: Karakteristik dasar subjek tidak menunjukkan perbedaan yang bermakna antara kedua kelompok. Rata-rata saat memulai hubungan seksual pada kedua kelompok adalah tiga bulan pascamelahirkan, dengan $p>0,05$. Tidak terdapat perbedaan yang bermakna antara kedua kelompok pada domain rangsangan dan lubrikasi masing-masing dengan $p=0,160$, dan $p=0,067$. Sedangkan domain lain yang menunjukkan perbedaan bermakna yaitu hasrat $(p=0,014)$, orgasme $(p=0,045)$, kepuasan $(p=0,018)$, nyeri $(p=0,02)$, dan skor total FSFI $(p=0,006)$. Ditemukan disfungsi seksual pada 18,60\% dari kelompok pascaepisiotomi dan 2,33\% pada pascaseksio sesarea, dengan nilai $p=0,030$.

Kesimpulan: Ditemukan perbedaan yang signifikan antara perempuan pascapersalinan pervaginam dengan episiotomi dan perempuan yang menjalani seksio sesarea.

[Maj Obstet Ginekol Indones 2014; 4: 199-203]

Kata kunci: episiotomi, fungsi seksual perempuan, seksio sesarea

Correspondence: I Made Wenata Jembawan, Department of Obstetrics and Gynaecology, University of Udayana, Denpasar, Bali. Mobile: 081236109596, email: wenata_jembawan@yahoo.com

\section{INTRODUCTION}

Most women will face pregnancy and the delivery process during the course of her life. The delivery process has an important influence on female sexual dysfunction. In daily practice, clinicians often forget about this aspect. However, the problem of female sexual dysfunction can affect a woman's quality of life, which also affect her partner and marriage life. ${ }^{1}$ To determine female sexual function, we used Female Sexual Function Index (FSFI) with total score of 26.55 categorized as sexual dysfunction. ${ }^{2}$

The delivery process can be spontaneous vaginal delivery and cesarean section. Although not employed as routine practice, mediolateral episiotomy is performed during most spontaneous vaginal de- 
liveries (especially in primiparous women) as prophylaxis from futher injury caused by fetal head passage. Conversely, episiotomy itself can cause pelvic floor dysfunction, pudendal nerve lesions, and other complications possibly affecting sexual function in the future. One of the benefit of cesarian section is less involvement of pelvic floor muscles, therefore preserving the sexual function, especially in elective cesarean sections. In emergency cesarean sections, trauma to the pelvic floor has already occurred. Moreover, numerous complications may result from the surgery that can also affect sexual dysfunction in the future. 3,4

\section{METHODS}

This study utilized a cross-sectional method. Eighty six primiparous women were enrolled in this study, consisting of 43 women who underwent spontaneous vaginal delivery with episiotomy and
43 women who underwent cesarean delivery. We did FSFI questionnaire in the respondent's house.

The inclusion criteria was married women, primiparous, who underwent spontaneous vaginal delivery with mediolateral episiotomy or cesarean delivery and delivered a living baby at the time of study. Subjects were also required to live with the husband who could have sexual intercourse in the last month and signed the informed consent. The exclusion criteria was previous history of medical problems, multiparity, delivery assisted by vacuum or forceps, perineal rupture grade III or IV, multiple gestation, history of misscariage, history of hormonal contraception use, and not having sexual intercourse in the last month.

\section{RESULTS}

The demographic characteristics of our study subjects are presented in Table 1 below.

Table 1. Demographic Characteristics

\begin{tabular}{|c|c|c|c|}
\hline Variables & $\begin{array}{l}\text { Post Episiotomy } \\
(n=43)\end{array}$ & $\begin{array}{l}\text { Post Cesarean Sec- } \\
\text { tion }(n=43)\end{array}$ & $\mathbf{p}$ \\
\hline Age (year) & 24.534 .23 & 23.724 .23 & 0.375 \\
\hline Education & & & 0.250 \\
\hline Uneducated & $0(0 \%)$ & $1(2.33 \%)$ & \\
\hline Primary school & $0(0 \%)$ & $4(9.30 \%)$ & \\
\hline Secondary school & $6(13.95 \%)$ & $6(13.95 \%)$ & \\
\hline High school & 35 (81.40\%) & $30(69.77 \%)$ & \\
\hline Graduate & $2(4.65 \%)$ & $2(4.65 \%)$ & \\
\hline Post-graduate & $0(0 \%)$ & $0(0 \%)$ & \\
\hline Occupation & & & 0.371 \\
\hline Housewife & $20(46.51 \%)$ & $18(41.86 \%)$ & \\
\hline Employee & 17 (39.53\%) & $23(53.49 \%)$ & \\
\hline Private worker & $4(9.30 \%)$ & $1(2.33 \%)$ & \\
\hline Civil worker & $2(4.65 \%)$ & $1(2.33 \%)$ & \\
\hline Pensioner & $0(0 \%)$ & $0(0 \%)$ & \\
\hline Payment & & & 1000 \\
\hline Insurance & 23 (53.49\%) & 23 (53.49\%) & \\
\hline Private & $20(46.51 \%)$ & $20(46.51 \%)$ & \\
\hline
\end{tabular}




\begin{tabular}{lccc}
\hline \multicolumn{1}{c}{ Variables } & $\begin{array}{c}\text { Post Episiotomy } \\
(\mathbf{n = 4 3 )}\end{array}$ & $\begin{array}{c}\text { Post Cesarean Sec- } \\
\text { tion (n=43) }\end{array}$ & p \\
\hline $\begin{array}{l}\text { Age (year) } \\
\text { Birth weight }\end{array}$ & 24.534 .23 & 23.724 .23 & 0.375 \\
$<2500 \mathrm{~g}$ & $12(27.91 \%)$ & $10(23.26 \%)$ & 0.621 \\
$2500-4000 \mathrm{~g}$ & $31(72.09 \%)$ & $33(76.74 \%)$ & 0.270 \\
$\quad 4000 \mathrm{~g}$ & $0(0 \%)$ & $0(0 \%)$ & 0.279 \\
Breastfeeding & $39(90.70 \%)$ & $36(83.72 \%)$ & $7(16.28 \%)$ \\
$\quad$ Yes & $4(9.30 \%)$ & & 0.596 \\
No & & $21(48.84 \%)$ & $22(51.16 \%)$ \\
Use of childcare support (babysitter) & $26(60.47 \%)$ & & \\
Yes & $17(39.53 \%)$ & $10(23.26 \%)$ & $33(76.74 \%)$ \\
No & & & \\
Presence of family problems & & & \\
Yes & $35(81.40 \%)$ & & \\
No &
\end{tabular}

Based on independent t-test, there was no significant difference in demographic characteristics ( $p>0.05$ ). The finding showed that demographic characteristic had no effect on the results. Time to first sexual intercourse after delivery in each group is shown in Table 2.
There was no difference in the time to first sexual intercourse $(p>0.05)$. The majority of subjects initiated sexual intercourse 3 months after delivery, both in post episiotomy group (60.47\%) and post cesarean group (46.51\%). We performed independent t-test to determine the difference of sexual function in both groups and the result is presented in Table 3.

Table 2. Time to First Sexual Intercourse after Delivery

\begin{tabular}{cccc}
\hline \hline Time to first sexual intercourse (months) & Post episiotomy (n=43) & Post cesarean section (n=43) & p \\
\hline 1 & $0(0 \%)$ & $0(0 \%)$ \\
2 & $11(25.58 \%)$ & $17(39.53 \%)$ \\
3 & $26(60.47 \%)$ & $20(46.51 \%)$ \\
4 & $6(13.95 \%)$ & $4(9.30 \%)$ \\
5 & $0(0 \%)$ & $2(4.65 \%)$ \\
6 & $0(0 \%)$ & $0(0 \%)$ \\
\hline
\end{tabular}


Table 3. Mean FSFI Score in Post Episiotomy and Post Cesarean Section

\begin{tabular}{|c|c|c|c|}
\hline Variable & Post episiotomy $(n=43)$ & Post cesarean section $(n=43)$ & $\mathbf{p}$ \\
\hline FSFI total score & 13.533 .02 & 14.900 .96 & 0.006 \\
\hline Desire & 4.701 .15 & 5.210 .62 & 0.014 \\
\hline Arousal & 4.901 .45 & $5.23 \quad 0.55$ & 0.160 \\
\hline Lubrication & 5.461 .21 & 5.830 .50 & 0.067 \\
\hline Orgasm & 5.431 .27 & 5.850 .45 & 0.045 \\
\hline Satisfaction & 5.161 .49 & 5.750 .56 & 0.018 \\
\hline Pain & 5.061 .62 & 5.890 .44 & 0.002 \\
\hline Sexual dysfunction (Score $\quad 26.55$ ) & & & \\
\hline Yes & $8(18.60 \%)$ & $1(2.33 \%)$ & 0.030 \\
\hline No & $35(81.40 \%)$ & $42(97.67 \%)$ & \\
\hline
\end{tabular}

Analysis of sexual function in both groups showed no significant difference $(p>0.05)$ in arousal and lubrication, whereas in terms of desire, orgasm, satisfaction, pain, FSFI total score, and sexual dysfunction there was a significant difference $(\mathrm{p}<0.05)$.

\section{DISCUSSION}

Decrease of sexual desire can be caused by trauma from spontaneous vaginal delivery, including pain and prolonged delivery process, therefore affecting sexual function. Moreover, sexual orientation in women after delivery also tend to change due to family priority where most women prioritize taking care of the baby, breastfeeding and using contraception. ${ }^{5}$ Incidence of loss of sexual desire after delivery is $53 \%$ in the first three months and $37 \%$ in the first six months postpartum, compared with $9 \%$ in previous pregnancy. ${ }^{6}$

Although sexual desire after delivery tend to decrease, when a women can focus on arousal from herself or her partner, it is not impossible for women to get through arousal phase. ${ }^{7}$ In "Sexual response circle" theory, arousal phase in women does not always follow desire. Sexual desire can be achieved after sexual arousal. ${ }^{8}$

Lubrication happens when women are stimulated both physically or mentally. ${ }^{9}$ If no problem occurs in the arousal phase, sexual desire can be achieved, as characterized by warm and ticklish feeling, lubrication, and vaginal muscle contraction. Moreover, if the woman was multiparous and during the delivery episiotomy was done properly, no further rupture occurred, and there was no delayed healing, it will not affect Bartholin gland's function in sexual reaction, so then lubrication process can start normally. ${ }^{10}$

In previous literatures, incidence of failure to achieve orgasm was 33\% in the the first three months and $23 \%$ in the first six months, compared to $14 \%$ who had this problem one year before pregnancy. This may be caused by perineal trauma, delayed wound healing or asymmetric wound, because the pain will make sexual intercourse uncomfortable. ${ }^{11}$ Failure to achieve orgasm usually leads to no sexual satisfaction, although there are other factors such as emotional bonding that can affect sexual satisfaction. ${ }^{8}$

Pain during sexual intercourse was found to be significantly different between the two groups in this study $(\mathrm{p}=0.02)$. This is concurrent with the findings of Baksu et al, who concluded that pain and satisfaction had the biggest effect towards FSFI score. ${ }^{1}$ According to Signorello et al, incidence of perineal pain was $42 \%$ in women after delivery and was significantly decreased to $22 \%$ and $10 \%$ at eight and twelve weeks after delivery. ${ }^{12}$

In general, this study showed that there is a significant difference in FSFI total score $(\mathrm{p}=0.006)$, and incidence of sexual dysfunction in both groups $(p=0.030)$. The result was similar with the study from Baksu et al who reported a significant decrease in total score in every domain of sexual function (desire, arousal, lubrication, orgasm, satisfaction, and pain) six months after vaginal delivery with episiotomy compared with before pregnancy. ${ }^{1}$ 
It is not easy to analyze female sexual function, we realized that there is time and sample limitation in this cross sectional study, so from this study we can only conclude that the sexual function in both groups are different. Although we could describe the sexual function in both groups, the effect of episiotomy and cesarean section towards sexual function after delivery has not been described yet. Our study also did not analyze sexual function before pregnancy and delivery in each groups with the assumption that the pregnancy itself shows the presence of good sexual function. There are numerous other factors also affecting sexual function after delivery that are not discussed here, such as the length of the $2^{\text {nd }}$ stage of labor, indication of cesarean section whether it is emergency or elective, postpartum depression, quality of breastfeeding, and other cultural factors. Therefore, further research is needed to complete the result of this study.

\section{CONCLUSION}

Based on our results, we can conclude that there is a significant difference in women sexual function between women who underwent vaginal delivery with episiotomy and women who underwent cesarean section in terms of desire, orgasm, satisfaction, pain, FSFI total score, and incidence of sexual dysfunction.

\section{REFERENCES}

1. Baksu B, Davas I, Agar E, et al. The effect of mode of delivery on postpartum sexual functioning in primiparous women. Int Urogynecol J Pelvic Floor Dysfunct 2007; 18(4): 401-6.

2. Meston, C. Validation of the Female Sexual Function Index (FSFI) in women with female orgasmic disorder and in women with hypoactive sexual desire disorder. J Sex Marital Therapy 2003; 29: 39-46.

3. Abdool Z, Thakar R, Sultan AH. Postpartum female sexual function: a review. Eur J Obstet Gynecol Reprod Biol 2009; 145(2): 133-7.

4. Liu T, Stern A, Roberts LJ, et al. The Isoprostanes: novel prostaglandin-like products of the free radical-catalyzed peroxidation of arachidonic acid. J Biomed Sci 1999; 6: 22635.

5. Rasjidi, I. Manual Seksio Sesarea \& Laparotomi Kelainan Adneksa, Berdasarkan Evidence Based. Jakarta: CV Sagung Seto; 2009.

6. Clayton AH. Prevalence of sexual dysfunction among newer antidepressants. J Clin Psychiatry 2002; 63(4): 357-66.

7. Barrett G, Pendry E, Peacock J, et al. Women's sexual health after childbirth. BJOG. 107(2): 186-95.

8. Windhu SC. Disfungsi Seksual: Tinjauan Fisiologi dan Patologis Terhadap Seksualitas. Yogyakarta: Mitra Husada; 2009.

9. Basson R. Revised definitions of women's sexual dysfunction. J Sexual Med 2004; 1(1): 40-8.

10. Rosen R. The Female Sexual Function Index (FSFI): a multidimensional self-report instrument for the assessment of female sexual function. J Sex Marital Therapy 2000; 26(2): 191-208.

11. Benson RC, Pernoll ML. Handbook of Obstetric and Gynaecology. 9th ed. New York: Mc Graw-Hill Inc; 1994: 362-72.

12. Signorello LB, Harlow BL, Chekos AK, et al. Postpartum sexual functioning and its relationship to perineal trauma: a retrospective cohort study of primiparous women. Am J Obstet Gynecol 2001; 184(5): 881-8. 